\title{
ОГЛЯДИ
}

УДК 576.32/.36 + 577.115 + 581.17

\section{SPHINGOSINE-1-PHOSPHATE: DISTRIBUTION, METABOLISM AND ROLE IN THE REGULATION OF CELLULAR FUNCTIONS}

\author{
V. I. MOROZOV', G. A. SAKUTA' ${ }^{2}$ M. I. KALINSKI \\ ${ }^{1}$ Sechenov Institute of Evolutionary Physiology and Biochemistry of the \\ Russian Academy of Sciences, St. Petersburg, Russia; \\ e-mail:vmorozov.g@gmail.com; \\ ${ }^{2}$ Institute of Cytology of the Russian Academy of Sciences, St. Petersburg, Russia; \\ ${ }^{3}$ Kent State University, Kent, OH, USA
}

The role of sphingosine-1-phosphate $(S 1 P)$ in regulation of cellular functions and cell protection is reviewed. S1P, along with other sphingolipid metabolites, is believed to act as an intracellular second messenger and as an extracellular mediator molecule. S1P chemistry, production and metabolism are described. Cellular receptors for S1P and their tissue specificity are described. Platelets and erythrocytes have a crucial significance in blood transport of S1P. Hypoxic conditions induce an increase in S1P, which initiates a set of cytoprotective events via its cellular receptors. S1P involvement in regulation of cell migration, myogenesis, control of skeletal muscle function is described. It is shown that S1P balance disturbances may mediate pathological state. S1P system implication in regulation of the most important cellular functions allows considering it as a prospective remedial target.

Key words: sphingosine-1-phosphate, receptors, distribution, metabolism, cellular functions regulation, cellular protection.

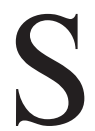
phingolipids are largely presented in cellular membranes where they play a role in membrane structure components. However, in the process of membrane lipid metabolism, sphingolipids are released and can be involved in regulation of the most important sides of cellular response. From a practical perspective it is important to consider sphingolipids as cytoprotectants and biomarkers which may be useful as therapeutic targets and diagnostic tools. This topic has recently received greater interest and was intensively reviewed during the last decade [1-10]. However, there is a need for an integral understanding of the novel experimental data that has resulted from increased attention to sphingolipids. This review focuses on sphingosine-1-phosphate (S1P) involvement in regulation of cellular functions and cellular protection.

\section{Chemistry, production and metabolism}

Chemistry. S1P is a signaling sphingolipid (lipid mediator) (Fig. 1). Sphingolipids are characterized by the presence of an aliphatic amino alcohol sphingosine.

Production. Sphingosine originates from the hydrolysis of ceramides by ceramidase (Fig. 2). Ceramides in turn, composed of sphingosine and a fatty acid, represent a lipid component of sphingomyelin, which is one of the major lipids of the cell membrane outward leaflet (about $85 \%$ of all cellular sphingolipids). Ceramide is believed to be involved in the regulation of cell proliferation, differentiation, and apoptosis. Sphingomyelin is hydrolyzed by sphingomyelinases (SMases) [11]. There are three main SMase types including the lysosomal and secreted acidic SMases (L- and S-

\footnotetext{
Abbreviations: CK, creatine kinase; dhS1P, dihydrosphingosine-1-phosphate; EDG, endothelial differentiation gene; ERK, extracellular signal-regulated kinase; HDL, high density lipoprotein; iNOS, inducible NO synthase; JNK, c-Jun N-terminal kinase; LDL, low density lipoprotein; LPA, lysophosphatidic acid; NO, nitric oxide; PAF, plateletactivating factor; PKC, protein kinase C; p38 MAP, mitogen-activated protein kinase; pVHL, Von Hippel-Lindau tumor suppressor; S1P, sphingosine-1-phosphate; S1P(1-5)R, S1P receptors; siRNA, small interfering RNA; SMase, sphingomyelinase; SphK, sphingosine kinase; STAT, signal transducer and activator of transcription; TGF- $\beta$, transforming growth factor- $\beta$; THP-1 monocytes (human acute monocytic leukemia cell line); TNF, tumor necrosis factor.
} 
<smiles>CCCCCCCCCCCCC/C=C/[C@H](O)[C@H](N)COP(=O)(O)O</smiles>

Fig. 1. Structure of Sphingosine-1-phosphate

ASMases) and the membrane neutral SMase (NSMase) [11]. Sphingolipid metabolites including S1P act as intracellular second messengers and as extracellular mediator molecules [12]. S1P enzymatic assay showed that S1P concentrations varied from 0.5 to $6 \mathrm{pmol} / \mathrm{g}$ wet weight in rat tissues [13]. The highest S1P concentration was detected in the brain whereas the lowest one was in the heart and testes. Sphingosine level appeared to be significantly higher in most cells and tissues as compared to S1P [13].

Metabolism. Three cell enzymes tightly regulate the S1P intracellular pool - sphingosine kinase (SphK), S1P lyase, and S1P phosphatase [14]. SphK phosphorylates sphingosine and sphingosine phosphatase catalyzes a removal of phosphate residue [15]. S1P lyase, a key enzyme of sphingolipid metabolism, is thought to be the only known enzyme that catalyzes irreversible degradation of sphingoid base-1-phosphates to phosphoethanolamine and the corresponding fatty aldehydes $[16,17]$. However, Ikeda et al [16] presented evidence of an alternative S1P-degrading enzyme in S1P lyase-null F9 cells which were able to degrade dihydrosphingosine. Both phosphoethanolamine and aldehyde are involved in glycerophospholipid synthesis. In most tissues S1P lyase expression is closely related to dihydroS1P lyase activity, however, high dihydroS1P lyase activity in the liver and heart are not correlated with enzyme protein levels [18]. In mice, S1P lyase is localized to the endoplasmic reticulum and its pyridoxal 5'-phosphate binding domain (active site) faces the cytosol, whereas S1P phosphatase has an opposite orientation in the endoplasmic reticulum [18]. The highest SphK1 expression in humans was found in adult lung and spleen, followed by peripheral blood leukocytes, thymus, and kidney, respectively. The enzyme expression was detected in the brain and heart [19]. Database searches revealed that endothelial cells, retinal pigment epithelium and senescent fibroblasts also expressed SphK1 [19].

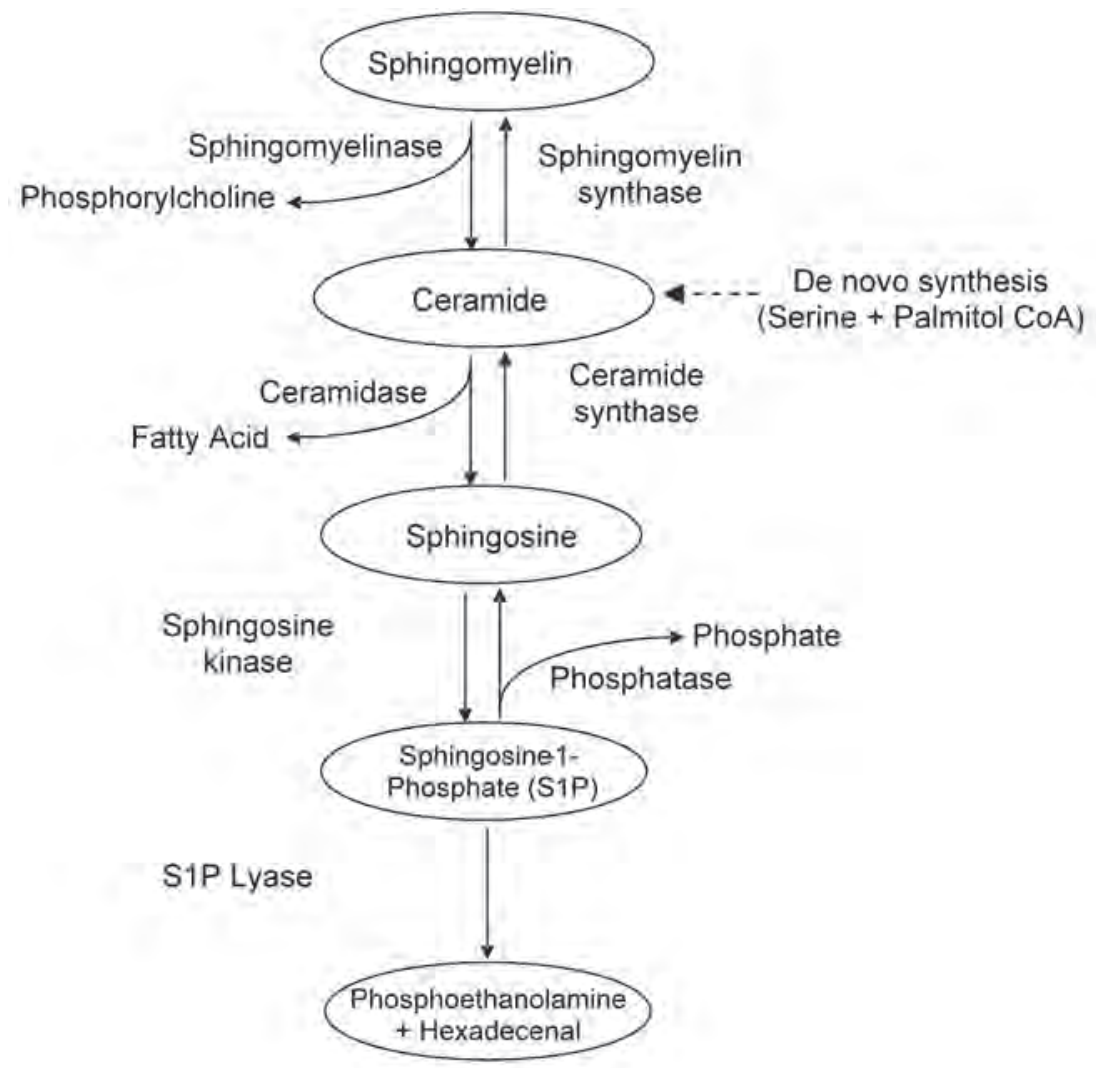

Fig. 2. Production and catabolism of sphingosine-1-phosphate 
There was strong staining for SphK1 in the white matter of the cerebrum and cerebellum, the red nucleus and cerebral peduncle in the midbrain, the uriniferous tubules in the kidney, and the vascular endothelial cells of various organs, and in megakaryocytes and platelets [20].

Lipid mediator S1P is short-lived in cells and its synthesis by SphKs may be sufficient to provide the necessary intracellular concentration of S1P [21]. SphK1 appeared to be a major isoform in many mouse tissues, particularly in the brain, heart, and colon; however, the authors found additional SphK activity in the spleen, small intestine, and lung that was not related to SphK1 and SphK2 [21]. Both enzymes may substitute for each other [22]. SphK1(-/-) mice appeared to be less resistant to LPS-induced lung damage as compared to wild type animals, but could be protected from damage by delivering the wild type SphK1 with adenoviral vector [23]. From distinctions in SphK1 and SphK2 expression during lung injury, the differing functions of enzymes in the LPS-induced lung damage mechanism were expected [23]. Deletion of the SphK1 gene resulted in a significant decrease in cardiomyocyte viability during 4 hours of hypoxia+glucose deprivation [24]. However, the comparison of neutrophil functions of SphK1 or SphK2 knockout mice failed to reveal any distinctions in superoxide production, $\beta$-glucuronidase release, or neutrophils' capacity to kill bacteria [25]. SphK1-deficient mice had normal acute and chronic inflammatory responses [26]. Nonetheless, in vivo SphK2 (not SphK1) knockout mice demonstrated faster aggravation of bacterial lung infection as compared to wild-type counterparts [25]. Therefore, the deficiency in one SphK isoform in mice may be sufficiently compensated by the second SphK isoform. However, the deletion of SphK1 and SphK2 resulted in embryonic death due to severe bleeding [27]. SphKs is considered as a regulator of the «sphingolipid rheostat» which produces pro-survival S1P and decreases pro-apoptotic sphingosine [28]. Liu et al. [29] assumed that SphK1 and SphK2 have opposite functions: SphK1 stimulates growth and survival whereas SphK2 enhances apoptosis and inhibits cellular proliferation. SphK2 amino acid analysis revealed a 9-amino acid motif presented in BH3-only proteins, a subgroup of Bcl-2 family pro-apoptotic proteins. This Bcl-2 homology domain-3 (BH3) may be responsible for SphK2's apoptotic effect [29]. SphK2 catalytic activity level may also be involved in apoptosis promotion via ceramide biosynthesis [30]. Time of survival of glioblastoma multiforme patients with low expression of SphK1 in tumors was prolonged as compared to patients who had high levels of enzyme expression [31]. In glioblastoma cell lines RNA interference to knockdown SphKs resulted in suppression of cell proliferation and increased apoptosis that were indicative of SphKs contribution to glioblastoma cells growth regulation [31]. Activation of SphKs by TNF- $\alpha$ was reported in human umbilical vein endothelial cells [32]. This mechanism was considered to be protective against the apoptotic TNF effect. Knowledge of lysophospholipid metabolism, tissue, and cell-specific receptor sets, and produced effects may provide a basis for synthesis of stimulators and inhibitors specified for specific function [33].

\section{Receptors}

S1P mediates such responses of the cell as growth, survival, and migration [15]. G-proteincoupled receptors of the endothelial differentiation gene (EDG) family are considered to be cell surface membrane-localized receptors for S1P [3, 34]. There are five subtypes of EDG receptors for S1P which are named S1P1, 2, 3, 4, and 5. Originally these were EDG-1, 5, 3, 6, and 8, respectively [14, 35]. S1P receptors are ubiquitous and are particularly present in the cardiovascular system [36]. Some of these receptors are involved in the development of the cardiovascular system [3, 14]. In murine ischemic hind limbs, exogenously administered S1P stimulated post-ischemic angiogenesis [37]. All S1P receptors are palmitoylated and $\mathrm{S} 1 \mathrm{P}(1) \mathrm{R}$ has three palmitoylated Cys residues in the cytoplasmic tail [38]. A palmitoylation/depalmitoylation cycle is needed for normal S1P(1) $\mathrm{R}$ internalization: non-palmitoylated $\mathrm{S} 1 \mathrm{P}(1) \mathrm{R}$ mutant cells demonstrated retarded S1P(1)R internalization. S1P(1-3)R are believed to play a protective role for vascular integrity and against acute myocardial ischemia [39]. Different S1P receptors may provide the various effects: $\mathrm{S} 1 \mathrm{P}(1) \mathrm{R}$ subtype on endothelial cells stimulates whereas S1P(2)R subtype inhibits tumor angiogenesis [40]. Therefore, varying expression of S1P receptors in different tissues specifies S1P effects.

\section{Blood transport and blood distribution}

The half-life of plasma S1P was reported to be approximately $15 \mathrm{~min}$, indicating a high level of S1P production [41]. After transportation out of the cell, S1P may act in autocrine, paracrine, or distant manner, reaching its receptors through blood and lymphatic vessels [14]. Via its receptors, S1P regulates functions of both major types of vascular cells - endothelial and smooth muscle cells [15, 42]. Using HPLC, Ito et al [43] compared platelet and erythrocyte contribution to the 
whole blood S1P balance and found that erythrocyte contribution was higher $(589 \mathrm{pmol}$ per $\mathrm{ml}$ blood) than that of platelets $(341 \mathrm{pmol} / \mathrm{ml})$, while S1P concentration in plasma was $153 \mathrm{pmol} / \mathrm{ml}$. When calculated per cell, one platelet appeared to contain approximately nine-fold higher S1P than did one erythrocyte. Erythocytes, when compared to platelets, had weak S1P kinase activity and lacked both S1P lyase and S1P phosphohydrolase activities degrading S1P [43]. Interestingly, nonactivated mouse platelets were devoid of S1P, but contained dhS1P in parallel with a high concentration of ceramide [44]. Platelet activation in vivo resulted in an immediate and continuous increase in dhS1P in plasma, whereas S1P was unchanged. In contrast, human platelets contained dhS1P along with S1P [44]. Rat platelet stimulation by thrombin or $\mathrm{Ca}^{2+}$ led to S1P release from platelets [45]. This is indicative of two independent plasma membrane systems regulating S1P release which may exist in platelets. The first system is thrombin-stimulated and ATP-dependent, while the second system is $\mathrm{Ca}^{2+}$-stimulated and ATP-independent [45]. Human platelets possess their own possibilities for S1P generation $[12,46]$. Platelets may 1) rapidly incorporate sphingosine from plasma and convert it into S1P and 2) generate S1P from degradation products of the platelet surface sphingomyelin, conceivably owing to the action of membrane-bound neutral ceramidase [12]. In vitro study demonstrated that the great portion of plasma S1P appeared to be connected with HDL and albumin fraction [46]. Ectophosphatase activity noticeably degraded S1P in the presence of vascular endothelial cells or in the whole blood whereas S1P was stable in plasma [46]. Erythrocytes are suggested to be the main source of plasma S1P [47, 48]. In human study, a strong positive correlation between S1P plasma concentration and erythrocyte-related rather than platelet-related parameters was found [49]. Alkaline ceramidase activity expressed in erythrocytes is responsible for sphingosine (precursor of S1P) generation in these cells [48]. S1P export from the erythrocyte is realized by means of an ATP-dependent transporter and S1P transport increases depending on S1P concentration [50].

HDL and serum albumin function as endogenous triggers for S1P release from erythrocytes and in bound form S1P may stimulate $\mathrm{Ca}^{2+}$ flux via S1P(1)R subtype [47]. Plasma S1P is thought to be very important in the maintenance of vascular integrity and the regulation of vascular leak in inflammation [51]. Mice with a genetic lack of plasma S1P demonstrated an increased vascular leak and impaired survival after anaphylaxis, administration of PAF or histamine, and exposure to related inflammatory challenges [51].
Hematopoietic cells release S1P into circulation (wild-type bone marrow transplantation to Sphk1(-/-)Sphk2(+/-) mice resulted in S1P plasma value restoration); however there was no significant alteration of S1P level in mice with thrombocytopenia, anemia, or leukopenia [41]. Vascular endothelial cells were also found to contribute to plasma S1P level [41]. Plasma S1P concentrations were significantly higher in men $(413.1 \pm 52.0 \mathrm{nmol} / \mathrm{L}$; mean $\pm \mathrm{SD})$ than in women $(352.4 \pm 39.7 \mathrm{nmol} / \mathrm{L})$ [49]. Therefore, plasma level of S1P depends on S1P release mainly from platelets, erythrocytes, and vascular endothelium. The main S1P blood portion is distributed among plasma lipids and serum albumin. Ectophosphatase may contribute to S1P degradation in circulation.

\section{Hypoxic conditions and cytoprotection}

Accumulating data indicate that S1P and its receptors play an important role in regulation of the cardiovascular system: cardiomyocyte, vascular smooth muscle, and endothelial cell function strongly depends on expression of S1P receptors and enzymes involved in sphigolipid metabolism [52]. Hypoxic conditions (both ischemic preconditioning and ischemic postconditioning) stimulate the heart to produce S1P, which acts as an effective cardioprotectant [53]. The comparison of cardiomyocytes in ischemic conditions $(4 \mathrm{~h}$ of hypoxia+glucose deprivation) in wild type and SphK1-null mice demonstrated that wild-type cells' viability was significantly higher [24]. Exgenous S1P considerably prevented cell death in both myocyte cultures. The activation of SphK1 by monoganglioside, GM-1, resulted in increased survival in wild-type cardiac myocytes. An application of S1P(1)R-selective antagonist VPC23019 or pertussis toxin before ischemic stress suppressed GM-1 effect. That is, S1P produced by myocytes must be exported from the cell where it can act as a paracrine or autocrine regulator via its receptors [24]. Infarct size in SphK1-null mice appeared to be increased and the hearts of these mice demonstrated a poor response to ischemic preconditioning or postconditioning stimulus [54]. VPC23019 blocked cardioprotection in ex vivo rat hearts and in isolated cardiomyocytes [55].

Cardioprotection. Since S1P was reported to be an important metabolite for survival of many tissues, it has been discussed as a cardioprotective agent [36]. Karliner et al [56] reported that S1P and LPA enhanced survival during hypoxia in neonatal rat cardiac myocytes. Lecour et al [57] found that the mechanism of TNF preconditioning-like resistance against infarction and contractile dysfunction depended on sphingolipid 
signaling: N-oleoylethanolamine, the sphingolipid signaling pathway inhibitor, reduced ischemic and TNF- $\alpha$ preconditioning effects.

Cardiomyocyte protection - receptors (phenomenon). S1P and other metabolites of sphingomyelin are thought to be relevant modulators of cardiovascular function and their action depends on specific cellular receptors [58]. Cardiac receptors for S1P and other sphingolipids have been discovered and classified [59]. S1P(1) receptors are important in S1P induced survival increase under hypoxic stress in mouse cardiac myocytes and this S1P effect may be removed by phosphoinositide 3-kinase suppression [60]. Tsukada et al [61] demonstrated that S1P(1)R has a crucial significance in ischemiareperfusion events: S1P (1 and $10 \mathrm{mM})$ decreased infarct size and creatine kinase release while S1P or S1P(1)R-selective agonist SEW2871 was able to improve left ventricular developed pressure. However, SEW2871 at a concentration of $1 \mathrm{mM}$ exacerbated reperfusion arrhythmias. Hoffmann et al [62] reported that new S1P receptor agonist FTY720 (2-amino-2-[2-(4-octylphenyl)ethyl]-1,3propanediol hydrochloride) pre- and post-conditioning improved a heart function recovery after infarction in rats due to a decrease in reperfusion arrhythmias. However, this drug administration failed to reduce infarct size and, moreover, when injected before reperfusion FTY720 increased rat mortality caused by fatal ventricular tachyarrhythmias [62]. Ischemia-reperfusion of hearts $(1 \mathrm{~h}$ of coronary occlusion and $2 \mathrm{~h}$ of reperfusion) in mice lacking either S1P(2)R or S1P(3)R failed to change infarct size as compared to wild-type mice, but it was increased by $>50 \%$ in $\operatorname{S1P}(2,3)$ receptor double-knockout mice [63]. Ischemia-reperfusionmediated activation of ERK, JNK, and p38 MAP kinases was similar in both $\operatorname{S1P}(2,3) \mathrm{R}$ doubleknockout and wild-type mice. However, doubleknockout mice demonstrated a diminished Act activation that was not observed, if deletion affected only one S1P receptor. S1P(3)R may be involved in regulation of heart rate [64]. These data suggest that S1P(2)R, S1P(3)R and receptor-mediated Act activation are involved in cardiomyocytes protection from ischemia-reperfusion injury [63].

Signaling. Jin et al [65] examined the hypothesis that an epsilon-isoform of protein kinase C (PKC epsilon) is involved in S1P-mediated cardioprotection. If hearts isolated from PKC epsilon knockout mice and wild-type mice were pretreated with a 2-min infusion of $10 \mathrm{nM}$ S1P before ischemia-reperfusion, they demonstrated an improved recovery of left ventricular developed pressure and creatine kinase release [65]. However, pretreatment with $10 \mathrm{nM}$ of the monoganglioside
GM-1, which increases S1P endogenous production, improved these variables only in wild-type hearts. These data indicated that an extracellular S1P cardioprotection mechanism omits PKC epsilon-dependent signaling pathways, whereas GM-1 acts via this mechanism. S1P and LPA antihypoxic protective action in relation to neonatal rat cardiac myocytes was shown through signaling mechanisms involving protein kinase $\mathrm{C}$ and mitochondrial K(ATP) channels [56]. S1P was able to activate, by means of S1P(1)R-mediated pathway, a mitogen-activated protein kinase (ERK) linked to antiapoptotic responses in the heart [66]. In fact, S1P pretreatment reduced hypoxia-reoxygenation induced death of isolated mouse cardiomyocytes, and an inhibition of various parts of the ERK pathway led to abrogation of this cell survival effect of S1P [66]. S1P-induced PKC epsilon translocation into mitochondria was indicative of this enzyme's involvement in a protective mechanism that included a reduction of the mitochondrial membrane depolarization and an increase in $\mathrm{Ca}^{2+}$ level in mitochondria [67]. Thus, S1P decreased the isolated mitochondria swelling induced by oxygen and glucose deprivation [67]. Agudo-Lypez et al [68] revealed dose-dependent effect of ceramide on mitochondrial permeability transition pore (mPTP). Low ceramide concentration treatment of mitochondria isolated from ischemia-exposed SH-SY5Y neuroblastoma cells resulted in reactive oxygen species (ROS)-induced controlled opening of the mPTP that could reduce mitochondrial $\mathrm{Ca}^{2+}$ overload and explain the sphingolipid protective mechanism. S1P-mediated $\mathrm{Ca}^{2+}$ overload in rat cardiomyocytes could be reduced by EDG-1 protein expression inhibition with EDG-1 antisense cDNA transfection [69]. S1P is implicated in the maintenance of increased peripheral resistance in heart failure via p38 MAPK-mediated deactivation of myosin light chain phosphatase [70]. This effect resulted in myogenic vasoconstriction and exacerbated heart failure. The absence of genes encoding sphingosine-kinases or $\mathrm{S} 1 \mathrm{P}(2) \mathrm{R}$ abrogated an elevated myogenic vasoconstriction after myocardium infarction [70]. A rat study in isolated perfused hearts with a novel S1P(3)R antagonist (TY-52156) demonstrated that vasoconstriction induced by S1P was realized through $\mathrm{S} 1 \mathrm{P}(3)$ receptor activation [71]. Subsequent events included an increase in $\mathrm{Ca}^{2+}(\mathrm{i})$ and $\mathrm{Rho}$ activation in vascular smooth muscle cells.

S1P with TGF- $\beta$ was equally shown to be implicated in hypoxia-inducible factor- $1 \alpha$ mRNA expression increase in macrophages under normoxia that may assist their transformation to a tumorsupporting phenotype [72]. Interestingly, the effect 
of acute or chronic hypoxia on the expression of genes involved in the production of S1P and on post S1P receptor signal transduction pathways were revealed in human pulmonary smooth muscle cells [73]. Both models of hypoxia failed to change the expression of S1P(1)R, S1P(3)R or LPA(1)R genes, whereas acute hypoxic exposure elevated mRNA transcript concentrations of SphK1/2 and LPP1. Chronic hypoxia raised SphK1 mRNA transcript alone. Moreover, in acute hypoxia, the ability of S1P to activate p38 MAPK was increased, whereas in chronic hypoxia the effect of S1P was more coupled with ERK-1/2 phosphorylation [73]. S1Pdependent murine heart ischemic preconditioning events induce an activation of SphK which is translocated from cytosol to cellular membranes whereas this effect was absent in PKC epsilon-knockout mice [74]. N,N-dimethylsphingosine, an inhibitor of the PKC epsilon, eliminated the ischemic preconditioning protective effect and preconditioning-induced increase in SphK activity [74].

$H D L . \mathrm{S} 1 \mathrm{P}$ is thought to be an important HDL component, defining HDL cardioprotective action [36]. HDL is a major carrier of S1P in plasma and animal data demonstrate that the lack of selected S1P receptors results in decreased HDL cardioprotective action [6, 36, 54]. HDL and its constituent, S1P, effectively protected mouse myocardium against ischemia-reperfusion damage in vivo. The diminution of infarct size was approximately $20 \%$ with HDL and $40 \%$ with S1P [75]. Authors suggest the underlying protective mechanism to include a suppression of inflammatory leukocyte recruitment and of apoptosis of cardiomyocytes in the area of infarction that was NO- and S1P(3) $\mathrm{R}$-mediated. The protective effect was lacking if NO synthase was inhibited or $\operatorname{S1P}(3) \mathrm{R}(-/-)$ mice were used [75, 76]. The viability of mouse cardiomyocytes in culture after hypoxia-reoxygenation was significantly increased in cells treated with autologous mouse HDL and this protective effect was absent if cardiomyocytes were treated with VPC 23019, the S1P(1)R and S1P(3)R antagonist [77]. HDL prosurvival action could also be inhibited by the selective $\mathrm{S} 1 \mathrm{P}(3) \mathrm{R}$ antagonist CAY10444, the G(i) antagonist pertussis toxin, the MEK (MAPK/ERK) kinase inhibitor PD-98059, and wortmannin (the phosphoinositide 3-kinase inhibitor). Therefore, HDL-mediated protection of cardiomyocytes against oxidative damage was needed to activate the signal pathways dependent on $\mathrm{S} 1 \mathrm{P}(1) \mathrm{R}$ and $\mathrm{S} 1 \mathrm{P}(3) \mathrm{R}$ subtypes [77].

SphK. When the post-conditioning protective effect was compared on wild and SphK1 null mouse isolated hearts, it appeared that SphK1 null hearts had no difference in infarct size from controls whereas wild-type hearts demonstrated a significant infarct size reduction from $40 \%$ in control to $29 \%$ in wild-type [78]. Preconditioning (two cycles of 2 min of global ischemia and $2 \mathrm{~min}$ of reperfusion) followed by ischemia-reperfusion (50 min global ischemia and $40 \mathrm{~min}$ reperfusion) failed to protect SphK1 null mouse hearts: the mutants demonstrated a worsening of cardiac functional variables and increase in infarct size as compared to wild-type animals, indicating the critical importance of the SphK1-S1P pathway in heart ischemic preconditioning [79]. In addition, ischemia-reperfusion initiated apoptosis in hearts appeared to be markedly elevated in SphK1 mouse mutant [79]. Kacimi et al., based on data from Sph1 null mouse cardiac fibroblasts hypothesized that SphK 1 has dual regulatory function: 1) control of cell proliferation (hypoxia-induced fibroblast proliferation was limited in SphK 1 null cells) and 2) negative modulation of hypoxia-induced pro-inflammatory responses [80].

Other sphingolipids. Other sphingolipids are also involved in cardiac status regulation. Sphingosine appeared to be a cardioprotectant and a physiological concentration 0.4 microM of sphingosine was as effective as 5 microM S1P [53]. When used in pre- or post-conditioning ex vivo rat heart models, both compounds provided more than $75 \%$ recovery of left ventricular developed pressure during reperfusion and a reduction in size of infarct from $45 \%$ to less than $8 \%$ after 40 -min ischemia. Combined application of both compounds provided an enhancement of the protective effect against ischemia for up to $90 \mathrm{~min}$ and a combination of S1P, sphingosine, and a ramped ischemic postconditioning regimen gave an additional heart protective effect [81]. Bielawska et al [82] were the first to demonstrate in vitro and in vivo that ceramide signaling can be involved in ischemia/reperfusion-induced cardiomyocytes apoptosis. Using a left coronary artery occlusion model in rat hearts they found ceramide to accumulate during ischemia progress (155 and 330\% baseline level after 30 and $210 \mathrm{~min}$ of ischemia, respectively). However, reperfusion was needed for the promotion of cardiomyocytes apoptosis [82]. S1P increase under hypoxia correlated with a decrease in cellular ceramide that might be explained by sphingomyelinase inhibition. Exogenous ceramide and ceramidase inhibition diminished hypoxiainduced cell growth [83]. In parallel to S1P, sphingosylphosphocholine (SPC) was identified as the plasma and serum factor responsible for activating the inwardly rectifying $\mathrm{K}^{+}$channel, and it has been suggested that both compounds may play a physiological role in heart regulation [58]. The molecular cardioprotective mechanisms used by S1P and 
sphingosine are different [53]. S1P uses a G-protein coupled receptor pathway while sphingosine acts via a cyclic nucleotide-dependent protein kinase pathway [81]. Ethanolamine, which is a S1P and anandamide ( $\mathrm{N}$-arachidonoylethanolamine, an endogenous cannabinoid neurotransmitter) biodegradation product, also appeared to possess cardioprotective properties in an isolated heart ischemia/reperfusion mouse model (30 min ischae$\mathrm{mia} / 2 \mathrm{~h}$ reperfusion) [84]. The protective effect occurred via activation of the STAT-3 signal pathway: infarct size was decreased by ethanolamine pretreatment in the wild-type mouse heart, whereas cardiomyocyte specific STAT-3 knockout mice demonstrated a loss of a protective effect [84]. Mitochondrial monoamine oxidase (isoform A) is important in mitochondrial ROS production, ROS-initiated cardiomyocyte apoptosis, and postischemic cardiac injury [85]. In H9c2 cardiomyoblasts, it was demonstrated that apoptosis may be linked to SphK1 inhibition by ROS that was associated with an accumulation of the proapoptotic agent ceramide [86]. Pharmacological or siRNAinduced SphK1 suppression, as well as ceramide or $\mathrm{H}_{2} \mathrm{O}_{2}$ delivery, enhanced $\mathrm{H} 9 \mathrm{c} 2$ cell apoptosis, whereas increased SphK1 expression protected cardiomyoblasts from apoptosis induced by serotonin or $\mathrm{H}_{2} \mathrm{O}_{2}$. When wild-type-mice and monoamine oxidase-A-deficient mice were compared in cardiac ischemia-reperfusion effects, SphK1 inhibition, ceramide accumulation, and concomitantly infarct size and cardiomyocyte apoptosis appeared to be significantly less in monoamine oxidase-Adeficient mice [86]. S1P may be also implicated in adiponectin-induced cyclooxygenase-2 expression in rat neonatal cardiac myocytes, and inhibition of SphK1 reduced cyclooxygenase-2 expression [87]. Antiplatelet therapy in infarct patients may decrease plasma S1P level due to its release by activated platelets which may diminish myocardium protection [88].
Collectively, reviewed data has shown evidence for an importance of S1P, its receptors, and SphK 1 in supporting cardiomyocytes longevity (Fig. 3). S1P receptors and SphK 1 may be prospective targets in therapy of cardiac pathologies.

Other examples of cell protection: endothelial and smooth muscle cells. S1P can induce the accumulation of transcriptionally active vascular hypoxia-inducible factor-1 (HIF-1) $\alpha$ subunit in vascular endothelial and smooth muscle cells by means of von Hippel-Lindau tumour suppressor protein ( $\mathrm{pVHL}$ )-independent stabilization of HIF-1 $\alpha$ protein [89]. S1P is also involved in endothelial cell barrier regulation [90]. S1P can produce microvessel permeability suppression mediated by S1P(1)R [91, 92]. In human endothelial cells S1P induces platelet/endothelial cell adhesion molecule-1 (PECAM-1) tyrosine phosphorylation through G(i) and Src family kinases that is involved in platelet adhesion to the endothelium [93]. Endothelial cells pretreatment with S1P (1 microM, $30 \mathrm{~min})$ attenuated $\mathrm{H}_{2} \mathrm{O}_{2}$-induced apoptosis due to decreased phosphorylation of p38 MAP kinase [94]. S1P delivered intravenously was able to significantly reduce both alveolar and vascular barrier dysfunction (lung edema and accumulation of extravascular lung water) induced in mice or dogs by intrabronchial endotoxin administration combined with high tidal volume mechanical ventilation $[95,96]$. Moreover, as a systemic tissue barrier regulator, S1P reduced LPS-mediated Evans blue dye albumin extravasation and myeloperoxidase content in renal tissues [96]. Intratracheal administration of LPS, resulted in an increase in S1P lyase activity followed by a decrease in lung S1P levels, while elevation of lung S1P by application of S1P lyase inhibitor 2-acetyl-4(5)-[1(R),2(S),3(R),4tetrahydroxybutyl]-imidazole provided lung tissue protection that was mediated by attenuation of $\mathrm{p} 38$ MAPK and I- $\kappa \mathrm{B}$, IL-6 secretion, and endothelial barrier disruption via Racl activation [97].

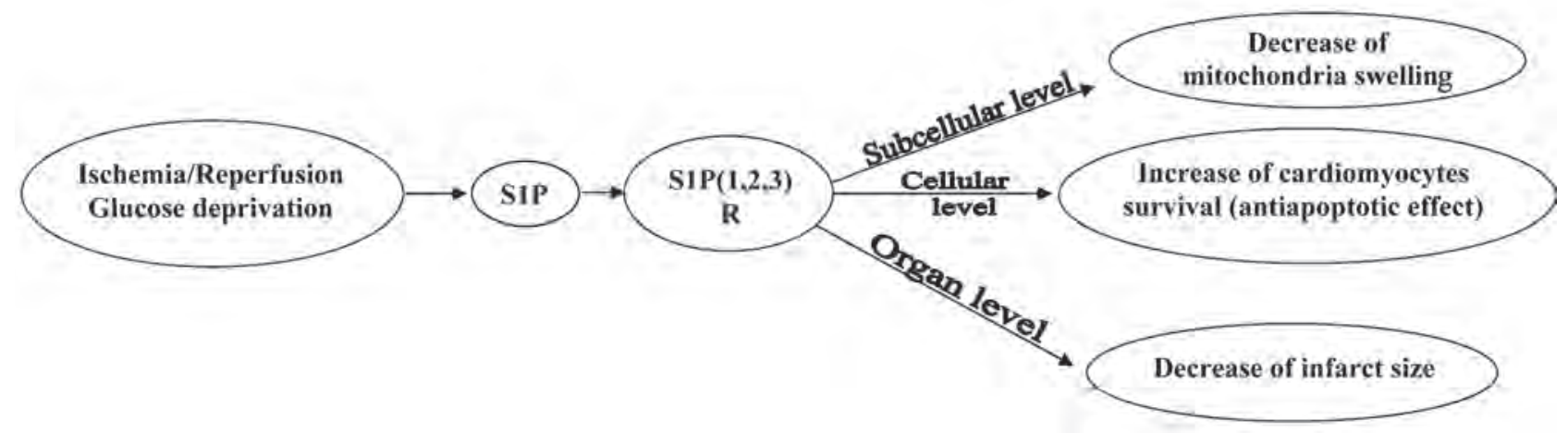

Fig. 3. Sphingosine-1-phosphate and cardiomyocytes survival 
S1P significantly prevented necrotic and apoptotic death of SH-SY5Y human neuroblastoma cells under oxygen and glucose deprivation [67]. Hypoxia up-regulated SphK1 in human endothelial cells EA.hy 926, stimulating the migratory response of the cells. An increased migration ability of endothelial cells may be associated with angiogenesis in tumor growth [98]. Vascular smooth muscle cells exposed to acute hypoxic stress $(\leq 16 \mathrm{~h} ; 2$ and $5 \% \mathrm{O}_{2}$ ) demonstrated significant stimulation of growth compared to normoxia $\left(21 \% \mathrm{O}_{2}\right)$ [83]. S1P synthesis was significantly increased in hypoxia and a pretreatment of cells with D-erythro-N,Ndimethylsphingosine, an inhibitor of sphingosine kinase, resulted in significant suppression of hypoxia's effect on cell growth.

Ionizing radiation activates acidic SMase producing ceramide, which promotes cellular apoptosis induced by radiation; however, S1P demonstrates radioprotective properties [99-101]. The inhibiton of S1P lyase, which irreversibly degrades $\mathrm{S} 1 \mathrm{P}$, prolonged survival of mice after exposure to a dose of lethal ionizing radiation [102].

S1P family receptors were found on the surface of human coronary artery smooth muscle cells (CASMC), and S1P appeared to be a strong inductor of CASMC contraction, which was inhibited by JTE-013, an antagonist of S1P(2)R [103]. Experiments with $\mathrm{S} 1 \mathrm{P}(2) \mathrm{R}(-/-)$ knockout mice suggest that S1P(2)R had an important role in vascular function and normal hemodynamics [104].
Thus, data on S1P-induced protection of various cell types may be important for the development of new approaches in the therapy of tissue and vascular barrier dysfunctions.

S1P regulation of cell migration. Numerous studies have demonstrated that S1P is tighly involved in the regulation of cell migration and this S1P effect is one of the most important (Fig. 4). $\mathrm{S} 1 \mathrm{P}$ action on endothelial cells and angiogenesis is mediated by PAF: S1P significantly increased PAF synthesis by bovine aortic endothelial cells and p38 MAPK activation by S1P was an important step in PAF synthesis activation [105]. S1P- and LPAinduced endothelial cell migration is mediated by balanced response of G(i) and Rho signaling pathways which leads to cytoskeleton remodeling for cell migration [106].

S1P is thought to play a crucial role as a chemoattractant for bone marrow hematopoietic stem/progenitor cells [107]. S1P(1)R plays a key role in the control of lymphocyte egress and migration [108, 109]. S1P(1)R subtype and S1P gradient determine lymphocyte egress dynamics from the bone marrow [110]. T cells of knockin mice (S1p1r(S5A/S5A)) with C-terminal serinerich S1P(1)R motif mutation demonstrated delayed S1P(1)R internalization and disturbed desensitization after stimulation by agonist [111]. Agonistinduced lymphopenia in mutant mice was significantly delayed as compared to wild-type animals. $\mathrm{S} 1 \mathrm{P}(1) \mathrm{R}$ expression on the lymphocyte membrane

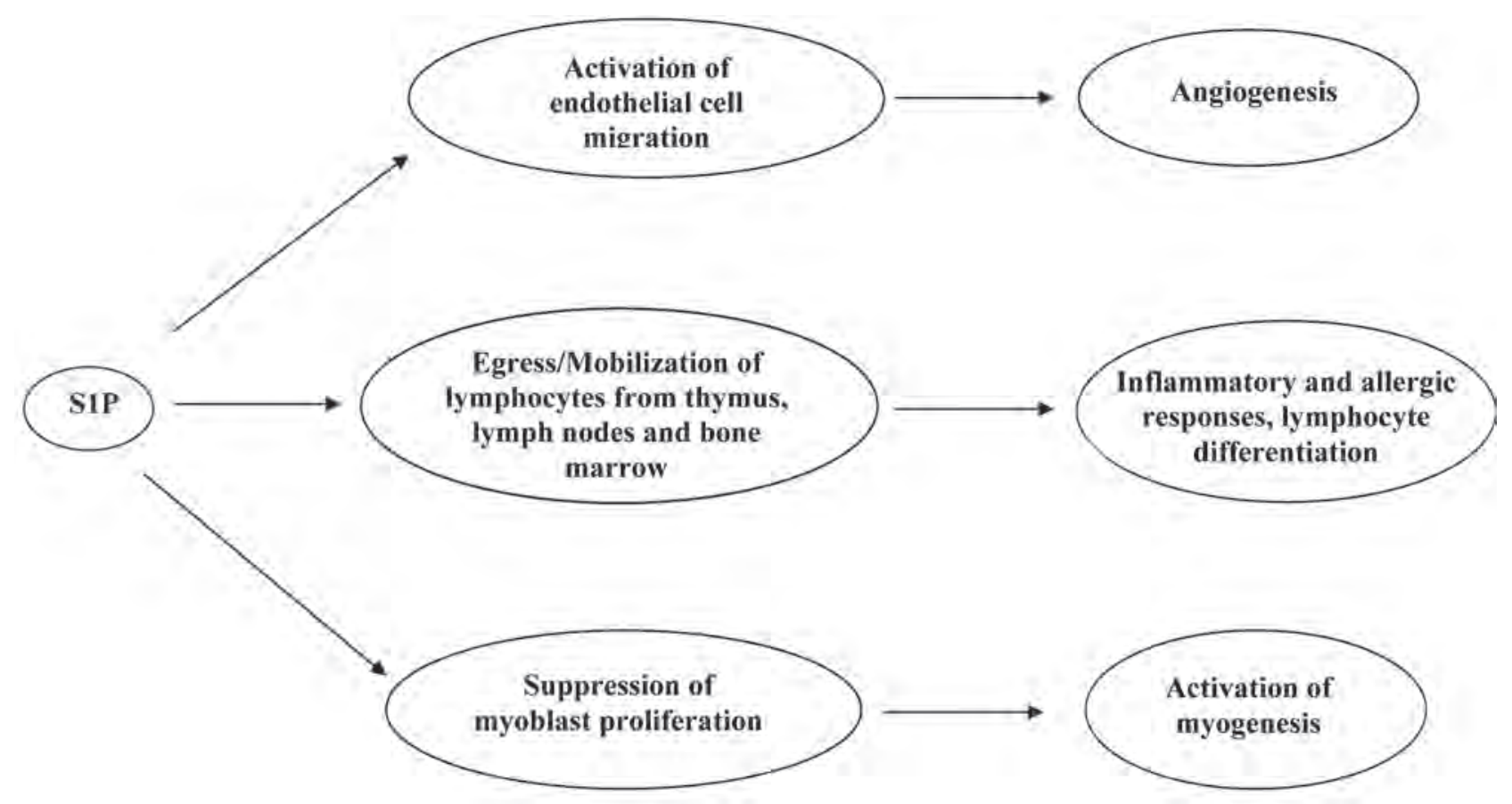

Fig. 4. Sphingosine-1-phosphate involvement in the control of cellular functions 
was involved in the maintenance of lymphocyte circulation and was crucial for egress of these cells from the thymus and lymph nodes [112, 113]. Internalization of S1P(1)R induced by treatment with its agonists or by S1P-lyase suppression stopped lymphocyte egress and resulted in a decrease of lymphocyte concentration in blood and lymph nodes [114]. PKC inhibition by staurosporine, calphostin C, and GF109203X resulted in S1P(1) $\mathrm{R}$ down-regulation on the cellular membrane surface of rat hepatoma HTC(4) cells, whereas its activation by phorbol 12-myristate 13-acetate partially abolished S1P(1)R down-regulation induced by FTY720 (PKC inhibitor) [113]. Hence, PKC-mediated down-regulation of S1P(1)R on the cell surface may be responsible for lymphopenia [113]. However, Sinha et al [115] brought evidence against S1P having a functional chemotactic role in the egress of B lymphocytes from lymph nodes. S1P delivery in endothelial cells led to E-selectin mRNA and protein expression and an increase in THP-1 monocytes number adhered to endothelial cells indicating an existence of an S1P-dependent mechanism of E-selectin expression regulation [116]. Hence, S1P may have an important role in the regulation of leukocyte trafficking and other cell migration.

\section{S1P and skeletal muscles}

Regulation of myogenesis. S1P receptors have been detected in skeletal muscle [117]. A S1P signaling pathway via $\mathrm{S} 1 \mathrm{P}(2) \mathrm{R}$ and activation of ERK1/ERK2 and p38 MAPK appeared to be important for the suppression of cell proliferation and stimulation of myogenic differentiation [118]. Up-regulation of gap junctional protein connexin-43 evoked by S1P may be involved in intercellular communication during the early phases of myoblast differentiation and down-regulation of connexin-43 blocked myogenesis [119]. Migratory capability of myoblasts is a property of great importance necessary for myogenesis. In compliance with data on S1P's significance in myogenesis regulation, enhanced SphK1 expression in confluent and differentiating $\mathrm{C} 2 \mathrm{C} 12$ myoblasts, as well as an arrest of $\mathrm{S} 1 \mathrm{P}(2)$-mediated myoblast growth were revealed [120] (Fig. 4). However, examination with suramin (a specific inhibitor of S1P(3)R) showed S1P(3)R to be the major receptor subtype for S1P's effect on intramembrane charge movements and L-type $\mathrm{Ca}^{2+}$ current. In skeletal muscle and myocardium sphingomyelin metabolites can interact with intracellular targets and alter intracellular $\mathrm{Ca}^{2+}$ release (via ryanodine receptors) and conductance of various ion channels in the plasma membrane [121, 122].

Skeletal muscle function control. Sphingolipids have been shown to be involved in the control of skeletal muscle function [123]. As in myocardium sphingosine may modulate calcium channels in skeletal muscle where it inhibits calcium release via the ryanodine receptor of the sarcoplasmic reticulum. Ceramide and sphingosine production are controlled by neutral SMase, which is located in the junctional transverse tubule membrane. Sphingosine-regulated events were suggested to be involved in malignant hyperthermia and muscle fatigue during muscle contraction [123].

There is evidence that exercise affects S1P and other sphingolipids metabolism in both skeletal muscles and blood [124-126]. Helge et al [124] compared sphingolipid content in vastus lateralis biopsies of trained and untrained humans at rest and after prolonged exercise. Exercise-induced muscle ceramide metabolism changes were found in both groups of subjects and it was proposed that the sphingolipid metabolites may be involved in muscle adaptation to exercise [124]. Untrained subjects demonstrated an increase in S1P and sphinganine-1-phosphate blood levels and a decrease in erythrocyte ceramide content after a single bout of exercise, whereas endurance trained subjects showed stable levels of sphingolipids in blood [126]. However, the basal plasma level of S1P in endurance trained subjects was higher compared to the untrained group, while sphingolipids (sphingosine, S1P, sphinganine-1-phosphate and ceramide) concentrations appeared to be reduced in erythrocytes. Plasma S1P increase during exercise may be one of the mechanisms providing favorable effects of physical training on the cardiovascular system [126]. Myocardial ceramide content and metabolism appear to depend on exercise duration, as 30-min of treadmill running led to decreased ceramide content in rat hearts, but prolonging exercise duration to $90 \mathrm{~min}$ normalized this variable, and running until exhaustion caused increased ceramide levels [127]. Changes in the activity of key enzymes in ceramide metabolism (serine palmitoyltransferase, sphingomyelinases, ceramidases) and sphingolipid intermediates content (ceramide, sphingosine, sphinganine, S1P) induced by running in skeletal muscles of rats also depended on duration of exercise [125]. Therefore, exercise affects metabolism of S1P and other sphingolipids in skeletal muscles indicating sphin- 
golipid involvement in the regulation of skeletal muscle functions.

\section{S1P status disturbance effects}

An alteration of the ability of tissue to metabolize sphingomielin normally may lead to pathologies [128]. For example, Niemann Pick disease is caused by sphingomyelin accumulation in the central nervous system due to a deficit of SMases [129], and an accumulation of sphingomyelin has been considered to be a risk factor for coronary heart disease [130]. Lipid mediators, including S1P, under certain conditions can play a role as athero- and thrombogenic molecules that may exacerbate cardiovascular diseases [131]. Cellular receptors are a pathway for beneficial or harmful effects of these mediators and a response may depend on receptor subtypes and the signaling pathways it activates in a defined cell [131]. S1P might produce $\mathrm{Ca}^{2+}$ overload in cardiomyocytes [69]. Blocking of S1P(1)R expression with an antisense approach caused a decrease in S1P-mediated $\mathrm{Ca}^{2+}$ deregulation, leading to speculation that S1P release by platelets during aggregation and thrombosis, may be involved in acute myocardial ischemia due to S1P's negative inotropic and cardiotoxic effects [69]. Because of its negative inotropic effects, S1P may induce bradycardia in mammalian hearts by means of altering in conductance of cell membrane ion channels resulting in action potential duration shortening in the atrium. S1P-treated mouse cardiomyocytes demonstrated a $25 \%$ reduction of shortening [132]. This action potential duration decrease is thought to depend on decreased $\mathrm{Ca}^{2+}$ influx resulting in intracellular $\mathrm{Ca}^{2+}$ decline and myocyte contractility decrease [132].

SphK1 overexpression in vivo has been associated with the degeneration and fibrosis of cardiomyocytes, in part owing to the $\mathrm{S} 1 \mathrm{P}(3) \mathrm{R}$ signaling activation by S1P [39]. SphK1 overexpression (a 20 -fold increase in enzymatic activity) in transgenic mice resulted in progressive heart degeneration and fibrosis development associated with embryonic genes up-regulation, elevation in RhoA and Racl activity, Smad3 phosphorilation stimulation, and an increase in oxidative stress markers. Fibrosis could be inhibited by treatment of juvenile transgenic mice with pitavastatin (an inhibitor of the Rho family $G$ proteins) or $\operatorname{SiP}(3) \mathrm{R}$ deletion which both associated with suppression of SphK1dependent Smad-3 phosphorylation. N-2-mercaptopropyonylglycine, an antioxidant, also suppressed fibrosis development [133]. S1P is thought to be involved in cardiac fibrosis due to excessive extracellular matrix production by myofibroblasts, which arise from injury-affected fibroblasts and suppression of cardiac function [134]. S1P increase led to an increased expression of myofibroblast marker, $\alpha$-smooth muscle actin, and collagen. These events were mediated by $\operatorname{S1P}(2) \mathrm{R}$. Rho kinase signaling and an increase in SphK1 expression and activity depended on TGF- $\beta$. SphK1 or S1P(2)R siRNA and an anti-S1P monoclonal antibody inhibited collagen production by cardiac fibroblasts [134]. Presumably, injury-initiated collagen production by cardiac fibroblasts depends on TGF- $\beta$-invoked «inside-out» S1P signaling which includes increased intracellular S1P synthesis by SphK1 followed by extracellular S1P release and S1P(2)R activation [134].

S1P(2)R-mediated S1P involvement in mouse liver regeneration and fibrosis after injury by $\mathrm{CCl}_{4}$ administration has also been demonstrated $[135,136]$. S1P(2)R(-/-) and wild-type mice responded to acute hepatic injury with similar necrosis, inflammation, and regeneration of hepatocytes, but hepatic myofibroblasts accumulation was diminished in S1P(2)R(-/-) mice [135]. The progression of $\mathrm{CCl}_{4}$-induced liver fibrosis (an increase in serum hyaluronic acid concentration) in rats was associated with a decrease in plasma S1P concentration [137]. Furthermore, decreased plasma S1P levels in chronic hepatitis $\mathrm{C}$ patients may be linked with liver fibrosis [137]. Hence, S1P and S1P(2)R may be considered as important components in the hepatic healing response to acute injury.

S1P may also be involved in atherosclerotic lesion formation through monocyte/macrophage chemotaxis regulation: thioglycollate-induced peritonitis was accompanied by a fast increase in S1P and macrophage accumulation in the peritoneal cavity, whereas FTY720 (an S1P analogue) reduced macrophage recruitment in mice [138]. In S1P(3)R-deficient mice, peritoneal macrophages demonstrated a loss of chemotaxis for S1P unlike those wild-type mice. S1P(3)R may contribute to monocyte/macrophage and smooth muscle cell accumulation in atherosclerotic lesions [138]. S1P may be also involved in an inflammatory process by means of cyclooxygenase- 2 induction through Galpha12 and $\operatorname{S1P}(1,3,5) \mathrm{R}$ [139]. Adiponectin (adipose-derived plasma protein) regulated cyclooxygenase-2 induction happens partly through S1P cellular receptors [140]. During chronic immobilization in rats, an increase in S1P was suggested, along with NO production via iNOS expression, NR1 expression and the activation of astrocytes, to be a cause of neurodegenerative changes [141]. Thus, disorders in sphingolipid metabolism and in particular the S1P-S1P receptors system and SphK may result in different negative consequences connected with cell and tissue disturbances. 


\section{S1P system as a prospective remedial target}

Evidence is accumulating to consider S1P and other phospholipids to be potential therapeutic targets [142, 143]. S1P G-protein-coupled receptors are also attractive targets for pharmacological treatment as numerous cellular functions are regulated via these receptors [144]. S1P(1)R regulates angiogenesis, vascular development, and immune cell trafficking whereas $\mathrm{S} 1 \mathrm{P}(2) \mathrm{R}$ plays a critical role in inner ear physiology, heart and vascular development, vascular remodelling, and vascular tone, permeability, and angiogenesis in vertebrates [144]. S1P(2)R preferentially acts through the $\mathrm{G}(12 / 13)$ pathway which is involved in the regulation of such intracellular signaling pathways as Rho GTPase, the phosphatase PTEN, and VE-cadherin-based adherens junctions [144].

In a murine model, S1P therapy appeared to completely prevent oocyte loss induced by radiation that leads to premature ovarian function failure and infertility [145]. The introduction of S1P in clinical medicine as an additional blood biochemical variable was at first considered to be an important and promising task connected with vascular therapy [35, 146]. Treatment directed toward the elevation of blood HDL contained S1P may be considered as a prospective strategy in high-risk cardiologic patients [147]. S1P injected in diabetic mice $\mathrm{db} / \mathrm{db}$ accelerated experimental cutaneous wound healing as compared to diabetic control due to acceleration of the neo-vascularization process [148]. S1P injected locally into wild-type mice or its endogenous overproduction in SphK1-transgenic mice promoted angiogenesis and blood flow recovery in ischemic hind limbs after femoral arteriectomy [149]. Thus, S1P and its receptors may be considered as promising targets for ischemia treatment. S1P's ability to promote differentiation and migration of keratinocytes assumed its role in wounds healing processes [150].

The use of S1P receptors agonists may also prove to be useful. Fingolimod (FTY720) is the first S1P receptor modulator, appeared to be highly effective in clinical trials aimed to treating multiple sclerosis possibly due to its capability to decrease S1P-driven egress of lymphocytes - including autoaggressive TH17 cells from lymph nodes [151, 152]. When prophylactically administrated to animals with experimental autoimmune encephalitis (a model for multiple sclerosis), FTY720 completely averted the disease progress. Additionally, therapeutic FTY720 administration caused significant mitigation of the clinical manifestation of encephalitis [153]. Besides S1P receptor-mediated action, the FTY720 may act independently of these receptors: in RBL-2H3 mast cells FTY720 inhibited cytosolic phospholipase A2, which is a key enzyme in eicosanoids production [154]. Modifications of FTY720 modulate its functions [155, 156]. Phosphorylation of FTY720 is crucial to its efficacy: hydroxyl group elimination resulted in both acceleration of phosphorylation and greater efficiency in lymphopenia induction [155]. However, repeated administration of $\mathrm{S} 1 \mathrm{P}(1) \mathrm{R}$ agonists eliminated endothelial barrier-protective effects of S1P and can exacerbate vascular leak, fibrosis, and mortality after bleomycin-induced lung injury [157]. Hoffman et al [158] compared the effects of S1P, the selective S1P(1)R agonist SEW2871 and the $\mathrm{S} 1 \mathrm{P}(1 / 3) \mathrm{R}$ agonist FTY720, on isolated rat cardiomyocytes, isolated Langendorff-perfused rat hearts and human myocardial muscle strip preparations that underwent ischemia-reperfusion. Both agonists activate Akt that was associated with the epidermal growth factor receptor transactivation. In cardiomyocytes, SEW2871 administration before/after ischemia provided a protective effect against cell death. FTY720 demonstrated a protective effect in rat hearts in terms of attenuation of the rise in left ventricular end-diastolic pressure and improvement of the recovery of left ventricular developed pressure without limiting infarct size, whereas selective SEW2871 failed to aid functional recovery and, left ventricular end-diastolic pressure appeared higher [159]. The cardioprotective effect of FTY720 was also demonstrated in ex vivo rat hearts: FTY720 precluded ischemia-reperfusion associated arrhythmias and this protective effect was likely realized through Pak1 signaling [159]. On human umbilical vein endothelial cells (HUVECs), palmitoyl-L-carnitine, accumulating in ischemic heart, demonstrated a S1P-like effect of increasing the $\mathrm{Ca}^{2+}$ concentration in cells that responded to this compound as to an agonist of S1P [160].

Taking into consideration S1P's involvement in the regulation of leukocytes traffic and its concentration increase under inflammatory conditions (asthma, autoimmunity), S1P's role in immunity should be accepted [108, 143, 161, 162]. Lymphocyte homing can be altered by S1P receptor agonist - KRP-203 [163]. In a rat autoimmune myocarditis model, this agent appeared to be capable of effectively decreasing the inflammation area, heart weight/body weight ratio, left ventricular function, macrophages, and CD4 T cells in the myocardium and inflammatory cytokine expression. In peripheral blood, KRP-203 reduced CD4 and CD8 T cells, whereas B cells and granulocytes remained unchangeable [163]. FTY720, being structurally similar S1P analogue but functioning as an S1P antagonist which inhibits lymphocyte 
egress, may be valuable for immunosuppression to prevent allograft rejection or to treat T-lymphocyte-dependent inflammatory skin diseases (lupus erythematosus, psoriasis, and atopic dermatitis) [150]. When phosphorylated, FTY720 caused a prolonged internalization of $\mathrm{S} 1 \mathrm{P}(1) \mathrm{R}$ which led to lymphocyte migration impairment [161]. Interestingly, non-phosphorylated FTY720 induced apoptosis in the human microglia cell line HMO6, and human fibroblasts, whereas phosphorylated forms of FTY720 and SEW2871 lacked this peculiarity [164, 165]. Antiapoptotic action of phosphorylated FTY720 occurs via S1P(3)R subtype, an increase in Bcl-2 phosphorylation and changes in the mitochondrial membrane potential [164]. Phosphorylated FTY720 appears to be a strong inductor of S1P(1)R ubiquitinylation and proteosomal degradation [166]. Internalization and degradation of the receptor might be prevented by $\mathrm{S} 1 \mathrm{P}(1) \mathrm{R}$ antagonist VPC 44116. Oo et al. [166] assumed that S1P(1)R ubiquitinylation and proteasomal degradation depending on FTY720 targeting of S1P(1)R may determine the immunosuppressive and antiangiogenic properties of this compound.

In a rat model of acute lung injury induced by acute necrotizing pancreatitis, FTY720 appeared to be able to significantly decrease pulmonary inflammation and injury [167]. SEW2871, a S1P(1)-selective agonist, administration improves mouse renal injury induced by ischemia-reperfusion by means of lymphocyte egress suppression and the inhibition of pro-inflammatory factors [168]. FTY720 suppressed hepatocellular carcinoma recurrence after rat liver transplantation in rats [169] and also showed a neuroprotective effect after transient middle cerebral artery occlusion [170]. Efforts aimed at producing new S1P system modulators may lead to the discovery of new prospective compounds [171, 172]. Therefore, an up-to-date understanding of the mechanism of sphingolipid action will enable the identification of cellular receptors for S1P and enzymes involved in S1P metabolism as possible targets for medical treatment.

\section{S1P as a potential biomarker}

S1P's introduction to laboratory medicine has been discussed [146]. It was reported that S1P-content of HDL may serve as a potential cardiovascular risk marker [147]. Plasma S1P and sphinganine-1-phosphate concentrations in infarct patients appeared to be reduced approximately by $50 \%$ compared to controls immediately after hospital admission and five days later, whereas other variables (free sphingosine, free sphinganine, and ceramide) were unchanged [88]. S1P was revealed as a significant predictor of coronary artery disease, even more predictive than such usual risk factors as age, gender, family history of coronary artery disease, diabetes mellitus, lipid profile, hypertension, etc. [173].

In addition to the early methods of S1P quantitative measurement new and more sensitive methods for S1P routine analysis have been proposed $[13,174]$. Such new methods include matrix-assisted laser desorption/ionization time-of-flight mass spectrometry using a phosphate-capture molecule, as well as immobilized metal affinity chromatography (for selective extraction of S1P and dihydroS1P) followed by elution, derivatization and detection by high-performance liquid chromatography were described [175, 176]. However, new studies are needed to estimate the significance of S1P as a valuable specific biomarker and to provide simpler and cheaper methods of S1P analysis.

In summary, the literature on S1P and some other lysophospholipids is indicative of an important role of these lipid metabolites in the regulation of cellular function and in cell growth stimulation under hypoxic condition. The protective mechanism of the cell includes modulation of sphingomyelin metabolism that results in a reduction of total intracellular ceramide level with a concomitant increase in S1P formation. Pharmacological S1P receptor agonists have distinct effects on ischaemia-reperfusion injury. S1P agonists' efficacy, demonstrated in animal experiments, makes them potential candidates for pharmaceutical postconditioning therapy after cardiac ischemia. This pharmacological approach with modulators of S1P receptors may also be useful in a variety of pathological conditions. 
СФИНГОЗИН-1-ФОСФАТ:

РАСПРЕДЕЛЕНИЕ, МЕТАБОЛИЗМ И РОЛЬ В РЕГУЛЯЦИИ КЛЕТОЧНЫХ ФУНКЦИЙ

\section{В. И. Морозов, Г. А. Сакута М. И. Калинский}

${ }^{1}$ Федеральное государственное бюджетное учреждение науки Институт эволюционной физиологии и биохимии им. И. М. Сеченова РАН, Санкт-Петербург, Россия;

${ }^{2}$ Федеральное государственное бюджетное учреждение науки Институт цитологии

РАН, Санкт-Петербург, Россия;

${ }^{3}$ Кентский государственный университет, Кент, США;

e-mail: vmorozov.g@gmail.com

В обзоре проведен анализ роли сфинголипида сфингозин-1-фосфата (С1Ф) в регуляции клеточных функций и защите клеток. С1Ф наряду с другими сфинголипидными метаболитами рассматривают как внутриклеточный второй мессенджер и как внеклеточную медиаторную молекулу. Описаны продукция и метаболизм С1Ф, клеточные рецепторы и их тканевая специфичность. Показано значение тромбоцитов и эритроцитов крови в транспорте С1Ф. Установлено также, что гипоксия индуцирует увеличение С1Ф, который через свои клеточные рецепторы инициирует цепь цитопротективных событий. Приведены примеры цитопротекции, относящиеся к кардиомиоцитам, клеткам эндотелия и гладких мышц. Рассмотрено участие С1Ф в регуляции миграции клеток, миогенезе, контроле функций скелетных мышц. Представлены данные о том, что нарушения статуса С $1 \Phi$ может опосредовать патологические состояния, что указывает на возможность использования системы С $1 \Phi$ в качестве реальной и эффективной мишени для фармакологического воздействия.

К л юч е в ы е с л о в а: сфингозин-1фосфат, рецепторы, распределение, метаболизм, регуляция функций клеток, клеточная защита.

\section{СФІНГОЗИН-1-ФОСФАТ: РОЗПОДІЛ, МЕТАБОЛІЗМ І РОЛЬ В РЕГУЛЯЦІї КЛІТИННИХ ФУНКЦІЙ}

\author{
В. I. Морозов, Г. А. Сакута ${ }^{2}$, \\ М. I. Калинський
}

'Інститут еволюційної фізіології та біохімії ім. І. М. Сеченова РАН, Санкт-Петербург, Росія; ${ }^{2}$ Інститут цитології РАН, Санкт-Петербург, Росія; ${ }^{3}$ Кентский державний університет, Кент, США; e-mail: vmorozov.g@gmail.com;

В огляді проведено аналіз ролі сфінголіпіду сфінгозин-1-фосфату (С1Ф) в регуляції клітинних функцій і захисту клітин. С1Ф поряд з іншими сфінголіпідними метаболітами розглядають як внутрішньоклітинний другий месенджер і як позаклітинну медіаторну молекулу. Описано продукцію та метаболізм С1Ф, клітинні рецептори та їх тканинну специфічність. Показано значення тромбоцитів і еритроцитів крові в транспорті С1Ф. Встановлено, що гіпоксія індукує збільшення С1Ф, який через свої клітинні рецептори ініціює ланцюг цитопротекторних подій. Наведені приклади цитопротекції пов'язані 3 кардіоміоцитами, клітинами ендотелію та гладеньких м'язів. Розглянуто участь С1Ф у регуляції міграції клітин, міогенезу, контролю функцій скелетних м'язів. Представлені дані про те, що порушення балансу С1Ф може опосередковувати патологічні стани, що вказує на можливість використання системи С1Ф як реальної і ефективної мішені для фармакологічного впливу.

Кл юч ов і слова: сфінгозин-1-фосфат, рецептори, розподіл, метаболізм, регуляція функцій клітин, клітинний захист.

1. Spiegel S., Merrill A.H., Jr. // FASEB J. 1996. - 10, N 12. - P. 1388-1397.

2. Kupperman E., An S., Osborne N. et al. // Nature. - 2000. - 406, N 6792. - P. 192-195.

3. Hla T. // Prostaglandins. - 2001. - 64, N 1-4. - P. 135-142. 
4. Karliner J. C. // J. Cell Biochem. - 2004. - 92, N 6. - P. 1095-1103.

5. Alewijnse A. E., Peters S. L. // Eur. J. Pharmacol. - 2008. - 585, N 2-3. - P. 292302.

6. Karliner J. C. // J. Cardiovasc. Pharmacol. 2009a. - 53, N 3. - P. 189-197.

7. Morris A. J., Selim S., Salous A., Smyth S. S. // Trends Cardiovasc. Med. - 2009. - 19, N 4. P. 135-140.

8. Egom E. E., Ke Y., Solaro R. J., Lei M. // Prog. Biophys. Mol. Biol. - 2010a. - 103, N 1. P. 142-147.

9. Liu X., Zhang Q. H., Yi G. H. // Mol. Cell Biochem. - 2012. - 363, N 1-2. - P. 21-33.

10. Maceyka M., Harikumar K. B., Milstien S., Spiegel S. // Trends Cell Biol. - 2012. - 22, N 1. - P. 50-60.

11. Pavoine C., Pecker F. // Cardiovasc. Res. 2009. - 82, N 2. - P. 175-183.

12. Tani M., Sano T., Ito M., Igarashi Y. // J. Lipid Res. - 2005. - 46, N 11. - P. 2458-2467.

13. Edsall L. C., Spiegel S. // Anal. Biochem.1999. - 272, N 1. - P. 80-86.

14. Leong W. I., Saba J. D. // Biochimie. - 2010. 92, N 6. - P. 716-723.

15. Watterson K. R., Ratz P. H., Spiegel S. // Cell. Signal. - 2005. - 17, N 3. - P. 289-298.

16. Ikeda M., Kihara A., Kariya Y. et al. // Biochem. Biophys. Res. Commun. - 2005. 329, N 2. - P. 474-479.

17. Bourquin F., Riezman H., Capitani G., Grütter M. G. // Structure. - 2010. - 18, N 8. - P. 1054-1065.

18. Ikeda M., Kihara A., Igarashi Y. // Biochem. Biophys. Res. Commun. - 2004. - 325, N 1. P. 338-343.

19. Melendez A. J., Carlos-Dias E., Gosink M. et al. // Gene. - 2000. - 251, N 1. - P. 19-26.

20. Murate T., Banno Y., T-Koizumi K. et al. // J. Histochem. Cytochem. - 2001. - 49, N 7. P. 845-855.

21. Fukuda Y., Kihara A., Igarashi Y. // Biochem. Biophys. Res. Commun. - 2003. - 309, N 1. P. $155-160$.

22. Alemany R. R., van Koppen C. J., Danneberg K. et al. // Naunyn Schmiedebergs Arch. Pharmacol. - 2007. - 374, N 5-6. - P. 413-428.

23. Wadgaonkar R., Patel V., Grinkina N. et al. // Am. J. Physiol. Lung Cell Mol. Physiol. 2009. - 296, N 4. - P. L603-L613.

24. Tao R., Zhang J., Vessey D. A. et al. // Cardiovasc Res. - 2007. - 74, N 1. - P. 56-63.

25. Zemann B., Urtz N., Reuschel R. et al. // Immunol. Lett. - 2007. - 109, N 1. - P. 56-63.
26. Michaud J., Kohno M., Proia R. L., Hla T. // FEBS Lett. - 2006. - 580, N 19. - P. 46074612.

27. Mizugishi K., Yamashita T., Olivera A. et al. // Mol. Cell. Biol. - 2005. - 25, N 24. P. 11113-11121.

28. Hait N. C., Oskeritzian C. A., Paugh S. W. et al. // Biochim. Biophys. Acta. - 2006. - 1758, N 12. - P. 2016-2026.

29. Liu H., Toman R. E., Goparaju S. K. et al. // J. Biol. Chem. - 2003. - 278, N 41. - P. 4033040336.

30. Maceyka M., Sankala H., Hait N. C. et al. // J. Biol. Chem. - 2005. - 280, N 44. - P. 3711837129.

31. Van Brocklyn J. R., Jackson C. A., Pearl D. K. et al. // J. Neuropathol. Exp. Neurol. - 2005. 64, N 8. - P. 695-705.

32. Xia P., Wang L., Gamble J. R., Vadas M. A. // J. Biol. Chem. - 1999. - 274, N 48. P. 34499-34505.

33. Karliner J. S. // Biochim. Biophys. Acta. 2002. - 1582, N 1-3. - P. 216-221.

34. Taha T. A., Argraves K. M., Obeid L. M. // Biochim. Biophys. Acta. - 2004. - 1682, N 1-3. - P. 48-55.

35. Yatomi Y. // Curr. Pharm. Des. - 2006. - 12, N 5. - P. 575-587.

36. Kennedy S., Kane K. A., Pyne N. J., Pyne S. // Curr. Opin. Pharmacol. - 2009. - 9, N 2. P. 194-201.

37. Qi X., Okamoto Y., Murakawa T. et al. // Eur. J. Pharmacol. - 2010. - 634, N 1-3. - P. 121-131.

38. Ohno Y., Ito A., Ogata R. et al. // Genes Cells. - 2009. - 14, N 8. - P. 911-923.

39. Takuwa Y., Okamoto Y., Yoshioka K., Takuwa N. // Biochim. Biophys. Acta. - 2008. - 1781, N 9. - P. 483-488.

40. Du W., Takuwa N., Yoshioka K. et al. // Cancer Res. - 2010. - 70, N 2. - P. 772-781.

41. Venkataraman K., Lee Y. M., Michaud J. et al. // Circ. Res. - 2008. - 102, N 6. - P. 669-676.

42. Allende M. L., Proia R. L. // Biochim. Biophys. Acta. - 2002. - 1582, N 1-3. - P. 222-227.

43. Ito K., Anada Y., Tani M. et al. // Biochem. Biophys. Res. Commun. - 2007. - 357, N 1. P. 212-217.

44. Dahm F., Nocito A., Bielawska A. et al. // J. Thromb. Haemost. - 2006. - 4, N 12. P. 2704-2709.

45. Kobayashi N., Nishi T., Hirata T. et al. // J. Lipid Res. - 2006. - 47, N 3. - P. 614-621.

46. Aoki S., Yatomi Y., Ohta M. et al. // J. Biochem. - 2005. - 138, N 1. - P. 47-55.

47. Bode C., Sensken S. C., Peest U. et al. // J. Cell. Biochem. - 2010. - 109, N 6. - P. 1232-1243. 
48. Xu R., Sun W., Jin J. et al. // FASEB J. 2010. - 24, N 7. - P. 2507-2515.

49. Ohkawa R., Nakamura K., Okubo S. et al. // Ann. Clin Biochem. - 2008. - 45, Pt 4. P. 356-363.

50. Kobayashi N., Kobayashi N., Yamaguchi A., Nishi T. // J. Biol. Chem. - 2009. - 284, N 32. - P. 21192-21200.

51. Camerer E., Regard J. B., Cornelissen I. et al. // J. Clin. Invest. - 2009. - 119, N 7. - P. 18711879.

52. Peters S. L., Alewijnse A. E. et al. // Curr. Opin. Pharmacol. - 2007. - 7, N 2. - P. 186-192.

53. Vessey D. A., Li L., Kelley M. et al. // J. Biochem. Mol. Toxicol. - 2008b. - 22, N 2. P. 113-118.

54. Karliner J. S. // Cardiovasc. Res. - 2009b. 82, N 2. - P. 184-192.

55. Vessey D. A., Li L., Honbo N., Karliner J. S. // Am. J. Physiol. Heart Circ. Physiol. - 2009. 297, N 4. - P. H1429-H1435.

56. Karliner J. S., Honbo N., Summers K. et al. // J. Mol. Cell. Cardiol. - 2001. - 33, N 9. P. 1713-1717.

57. Lecour S., Smith R. M., Woodward B., et al. // J. Mol. Cell. Cardiol. - 2002. - 34, N5. P. 509-518.

58. Liliom K., Sun G., Bbnemann M. et al. // Biochem. J. - 2001. - 355, Pt 1. - P. 189-197.

59. Bünemann M., Liliom K., Brandts B. K. et al. // EMBO J. - 1996. - 15, N 20. - P. 5527-5534.

60. Zhang J., Honbo N., Goetzl E. J. et al. // Am. J. Physiol. Heart Circ. Physiol. - 2007. - 293, N 5. - P. H3150-H3158.

61. Tsukada Y. T., Sanna M. G., Rosen H. et al. // J. Cardiovasc. Pharmacol. - 2007. - 50, N 6. - P. 660-669.

62. Hofmann U., Hu K., Walter F. et al. // Br. J. Pharmacol. - 2010. - 160, N 5. - P. 12431251.

63. Means C. K., Xiao C. Y., Li Z. et al. // Am. J. Physiol. Heart Circ. Physiol. - 2007. - 292, N 6. - P. H2944-H2951.

64. Sanna M. G., Liao J., Jo E. et al. // J. Biol. Chem. - 2004. - 279, N 14. - P. 13839-13848.

65. Jin Z. Q., Zhou H. Z., Zhu P. et al. // Am. J. Physiol. Heart Circ. Physiol. - 2002. - 282, N 6. - P. H1970-H1977.

66. Tao R., Hoover H. E., Zhang J. et al. // J. Cardiovasc. Pharmacol. - 2009. - 53, N 6. P. 486-494.

67. Agudo-Lypez A., Miguel B. G., Fernández I., Martínez A. M. // Neurosci. Lett. - 2010. 470, N 2. - P. 130-133.

68. Agudo-Lypez A., Miguel B. G., Fernández I., Martínez A. M. // FEBS Lett. - 2011. - 585, N 1. - P. 99-103.
69. Nakajima N., Cavalli A. L., Biral D. et al. // Eur. J. Biochem. - 2000. - 267, N 18. P. 5679-5686.

70. Hoefer J., Azam M. A., Kroetsch J. T. et al. // Circ. Res. - 2010. - 107, N 7. - P. 923-933.

71. Takasugi H., Ohnuma S., Koide Y. et al. // Mol. Pharmacol. - 2010. - 77, N 4. - P. 704-713.

72. Herr B., Zhou J., Werno C. et al. // Blood. 2009. - 114, N 10. - P. 2140-2148.

73. Ahmad M., Long J. S., Pyne N. Y., Pyne S. // Prostaglandins Other Lipid Mediat. - 2006. 79, $N$ 3-4. - P. 278-286.

74. Jin Z. Q., Goetzl E. J., Karliner J. S. // Circulation. - 2004. - 110, N 14. - P. 19801989.

75. Theilmeier G., Schmidt C., Herrmann J. et al. // Circulation. - 2006. - 114, N 13. - P. 14031409.

76. Levkau B., Hermann S., Theilmeier G. et al. // Circulation. - 2004. - 110, N 21. - P. 33553359.

77. Tao R., Hoover H. E., Honbo N. et al. // Am. J. Physiol. Heart Circ. Physiol. - 2010. - 298, N 3. - P. H1022-H1028.

78. Jin Z. Q., Karliner J. S., Vessey D. A. // Cardiovasc. Res. - 2008. - 79, N 1. - P. 134-140.

79. Jin Z. Q., Zhang J., Huang Y. et al. // Cardiovasc. Res. - 2007. - 76, N 1. - P. 41-50.

80. Kacimi R., Vessey D. A., Honbo N., Karliner J. S. // J. Mol. Cell. Cardiol. - 2007. - 43, N 1. P. 85-91.

81. Vessey D. A., Li L., Kelley M., Karliner J. S. // Biochem. Biophys. Res. Commun. - 2008a. 375, N 3. - P. 425-429.

82. Bielawska A. E., Shapiro J. P., Jiang L. et al. // Am. J. Pathol. - 1997. - 151, N 5. - P. 12571263.

83. Yun J. K., Kester M. // Arch. Biochem. Biophys. - 2002, - 408, N 1. - P. 78-86.

84. Kelly R. F., Lamont K. T., Somers S. et al. // Basic Res. Cardiol. - 2010. - 105, N 6. P. 763-770.

85. Bianchi P., Kunduzova O., Masini E. et al. // Circulation. - 2005. - 112, N 21. - P. 32973305.

86. Pchejetski D., Kunduzova O., Dayon A. et al. // Circ. Res. - 2007. - 100, N 1. - P. 41-49.

87. Ikeda Y., Ohashi K., Shibata R. et al. // FEBS Lett. - 2008. - 582, N 7. - P. 1147-1150.

88. Knapp M., Baranowski M., Czarnowski D. et al. // Med. Sci. Monit. - 2009. - 15, N 9. P. CR490-CR493.

89. Michaud M. D., Robitaille G. A., Gratton J. P., et al. // Arterioscler. Thromb. Vasc. Biol. 2009. - 29, N 6. - P. 902-908.

90. McVerry B. J., Garcia J. G. // J. Cell. Biochem. - 2004. - 92, N 6. - P. 1075-1085. 
91. Adamson R. H., Sarai R. K., Altangerel A. et al. // Cardiovasc. Res. - 2010. - 88, N 2. P. 344-351.

92. Zhang G., Xu S., Qian Y., He P. // Am. J. Physiol. Heart Circ. Physiol. - 2010. - 299, N 5. - P. H1494-H1504.

93. Huang Y. T., Chen S. U., Chou C. H., Lee H. // Cell. Signal. - 2008. - 20, N 8. - P. 1521-1527.

94. Moriue T., Igarashi J., Yoneda K. et al. // Biochem. Biophys. Res. Commun. - 2008. 368, N 4. - P. 852-857.

95. McVerry B. J., Peng X., Hassoun P. M. et al. // Am. J. Respir. Crit. Care Med. - 2004. - 170, N 9. - P. 987-993.

96. Peng X., Hassoun P. M., Sammani S. et al. // Am. J. Respir. Crit. Care. Med. - 2004. - 169, N 11. - P. 1245-1251.

97. Zhao Y., Gorshkova I. A, Berdyshev E. et al. // Am. J. Respir. Cell. Mol. Biol. - 2011. - 45, N 2. - P. 426-435.

98. Schwalm S., Döll F., Römer I. et al. // Biochem. Biophys. Res. Commun. - 2008. - 368, N 4. P. 1020-1025.

99. Gulbins E., Jekle A., Ferlinz, K. et al. // Am. J. Physiol. Renal Physiol. - 2000. - 279, N 4. P. F605-F615.

100. Moeller B. J., Pasqualini R., Arap W. // Cancer Biol. Ther. - 2009. - 8, N 1. - P. 64-65.

101. Bonnaud S., Niaudet C., Legoux F. et al. // Cancer Res. - 2010. - 70, N 23. - P. 99059915.

102. Kumar A., Oskouian B., Fyrst H. et al. // Cell Death Dis. - 2011. - 2, N 2. - P. e119.

103. Ohmori T., Yatomi Y., Osada M. et al. // Cardiovasc. Res. - 2003. - 58, N 1. P. $170-177$.

104. Lorenz J. N., Arend L. J., Robitz R. et al. // Am. J. Physiol. Regul. Integr. Comp. Physiol. 2007. - 292, N 1. - P. R440-R446.

105. Bernatchez P. N., Tremblay F., Rollin S. et al. // J. Cell. Biochem. - 2003. - 90, N 4. P. 719-731.

106. Panetti T. S., Nowlen J., Mosher D. F. // Arterioscler. Thromb. Vasc. Biol. - 2000. 20, N 4. - P. 1013-1019.

107. Ratajczak M. Z., Lee H., Wysoczynski M. et al. // Leukemia. - 2010. - 24, N 5. - P. 976-985.

108. Mandala S., Hajdu R., Bergstrom J. et al. // Science. - 2002. - 296, N 5566. - P. 346-349.

109. Wei S. H., Rosen H., Matheu M. P. et al. // Nat. Immunol. - 2005. - 6, N 12. - P. 12281235.

110. Maeda Y., Seki N., Sato N. et al. // Int. Immunol. - 2010. - 22, N 6. - P. 515-525.

111. Thangada S., Khanna K. M., Blaho V. A. et al. // J. Exp. Med. - 2010. - 207, N 7. P. 1475-1483.
112. Sanna M. G., Liao J., Jo E. et al. // J. Biol. Chem. - 2004. - 279, N 14. - P. 1383913848.

113. Sensken S. C., Gräler M. H. // Ibid. - 2010. 285, N 9. - P. 6298-6307.

114. Schwab S. R., Pereira J. P., Matloubian M. et al. // Science. - 2005. - 309, N 5741. P. 1735-1739.

115. Sinha R. K., Park C., Hwang I. Y. et al. // Immunity. - 2009. - 30, N 3. - P. 434-446.

116. Weis T., Völker W., Holtwick R. et al. // Eur. J. Cell Biol. - 2010. - 89, N 10. - P. 733-741.

117. Bencini C., Squecco R., Piperio C. et al. // J. Muscle Res. Cell Motil. - 2003. - 24, N 8. P. 539-554.

118. Donati C., Meacci E., Nuti F. et al. // FASEB J. - 2005. - 19, N 3. - P. 449-451.

119. Squecco R., Sassoli C., Nuti F. et al. // Mol. Biol. Cell. - 2006. - 17, N 11. - P. 48964910.

120. Meacci E., Nuti F., Donati C. et al. // J. Cell. Physiol. - 2008. - 214, N 1. - P. 210-220.

121. Needleman D. H., Aghdasi B., Seryshev A. B. et al. // Am. J. Physiol. - 1997. - 272, N 5 Pt 1. - P. C1465-C1474.

122. Sharma C., Smith T., Li S. et al. // Chem. Phys. Lipids. - 2000. - 104, N 1. - P. 1-11.

123. Sabbadini R. A., Danieli-Betto D., Betto $R$. // Ital. J. Neurol. Sci. - 1999. - 20, N 6. P. 423-430.

124. Helge J. W., Dobrzyn A., Saltin B., Gorski J. // Exp. Physiol. - 2004. - 89, N 1. - P. 119-127.

125. Błachnio-Zabielska A., Baranowski M., Zabielski P., Gyrski J. // J. Cell. Biochem. 2008. - 105, N 3. - P. 776-784.

126. Baranowski M., Charmas M., Długołęcka B., Gyrski J. // Acta Physiol. (Oxf). - 2011. 203, N 3. - P. 373-380.

127. Baranowski M., Zabielski P., Blachnio A., Gorski J. // Ibid. - 2008. - 192, N 4. P. 519-529.

128. Payne S., Lee S. C., Long J., Pyne N. J. // Cell. Signal. - 2009. - 21, N 1. - P. 14-21.

129. Chatterjee S., Kolmakova A., Miller M. // Curr. Opin. Investig. Drugs. - 2006. - 7, N 3. P. 219-228.

130. Jiang X. C., Paultre F., Pearson T. A. et al. // Arterioscler. Thromb. Vasc. Biol. - 2000. 20, N 12. - P. 2614-2618.

131. Siess $W$. // Biochim. Biophys. Acta. - 2002. 1582, N 1-3. - P. 204-215.

132. Landeen L. K., Dederko D. A., Kondo C. S. et al. // Am. J. Physiol. Heart Circ. Physiol. 2008. - 294, N 2. - P. H736-H749.

133. Takuwa N., Ohkura S., Takashima S. et al. // Cardiovasc. Res. - 2010. - 85, N 3. P. 484-493. 
134. Gellings N. L., Swaney J. S., Moreno K. M., Sabbadini R. A. // Ibid. - 2009. - 82, N 2. P. 303-312.

135. Serriere-Lanneau V., Teixeira-Clerc F., Li L. et al. // FASEB J. - 2007. - 21, N 9. P. 2005-2013.

136. Ikeda H., Watanabe N., Ishii I. et al. // J. Lipid Res. - 2009. - 50, N 3. - P. 556-564.

137. Ikeda H., Ohkawa R., Watanabe N. et al. // Clin. Chim. Acta. - 2010. - 411, N 9-10. P. 765-770.

138. Keul P., Lucke S., von Wnuck Lipinski K. et al. // Circ. Res. - 2011. - 108, N 3. - P. 314-323.

139. Ki S. H., Choi M. J., Lee C.H., Kim S. G. // J. Biol. Chem. - 2007. - 282, N 3. - P. 19381947.

140. Ikeda Y., Ohashi K., Shibata R. et al. // FEBS Lett. - 2008. - 582, N 7. - P. 1147-1150.

141. Jang S., Suh S. H., Yoo H. S. et al. // Neurochem Res. - 2008. - 33, N 5. - P. 842-851.

142. Toman R. E., Milstien S., Spiegel S. // Expert Opin. Ther. Targets. - 2001. - 5, N 1. P. 109-123.

143. Chi H. // Trends Pharmacol. Sci. - 2011. 32, N 1. - P. 16-24.

144. Skoura A., Hla T. // Cardiovasc. Res. 2009. - 82, N 2. - P. 221-228.

145. Spiegel S., Kolesnick R. // Leukemia. 2002. - 16, N 9. - P. 1596-602.

146. Yatomi $Y$. // Biochim. Biophys. Acta. 2008. - 1780, N 3. - P. 606-611.

147. Keul P., Sattler K., Levkau B. // Heart Fail. Rev. - 2007. - 12, N 3-4. - P. 301-306.

148. Kawanabe T., Kawakami T., Yatomi Y. et al. // J. Dermatol. Sci. - 2007. - 48, N 1. P. 53-60.

149. Oyama O., Sugimoto N., Qi X. et al. // Cardiovasc. Res. - 2008. - 78, N 2. P. 301-307.

150. Herzinger T., Kleuser B., Schäfer-Korting M., Korting H. C. // Am. J. Clin. Dermatol. 2007. - 8, N 6. - P. 329-336.

151. Chiba K. // Pharmacol. Ther. - 2005. - 108, N 3. - P. 308-319.

152. Brinkmann V. // Br. J. Pharmacol. - 2009. 158, N 5. - P. 1173-1182.

153. Chun J., Hartung H. P. // Clin. Neuropharmacol. - 2010. - 33, N 1. - P. 91-101.

154. Payne S. G., Oskeritzian C. A., Griffiths R. et al. // Blood. - 2007. - 109, N 3. - P. 10771085.

155. Jary E., Bee T., Walker S. R. et al. // Mol. Pharmacol. - 2010. - 78, N 4. - P. 685-692.

156. Valentine W. J., Kiss G. N., Liu J. et al. // Cell. Signal. - 2010. - 22, N 10. - P. 1543-1553.
157. Shea B. S., Brooks S. F., Fontaine B. A. et al. // Am. J. Respir. Cell. Mol. Biol. - 2010. 43, N 6. - P. 662-673.

158. Hofmann U., Burkard N., Vogt C. et al. // Cardiovasc. Res. - 2009. - 83, N 2. - P. 285293.

159. Egom E. E., Ke Y., Musa H. et al. // J. Mol. Cell. Cardiol. - 2010b. - 48, N 2. - P. 406414.

160. Muraki K., Imaizumi $Y$. // J. Pharmacol. Sci. - 2003. - 92, N 3. - P. 252-258.

161. von Wenckstern H., Zimmermann K., Kleuser B. // Arch. Immunol. Ther. Exp. (Warsz). 2006. - 54, N 4. - P. 239-251.

162. Rivera J., Proia R.L., Olivera A. // Nat. Rev. Immunol. - 2008. - 8, N 10. - P. 753-763.

163. Ogawa R., Takahashi M., Hirose S. et al. // Biochem. Biophys. Res. Commun. - 2007. 361, N 3. - P. 621-628.

164. Potteck H., Nieuwenhuis B., Lüth A. et al. // Cell. Physiol. Biochem. - 2010. - 26, N 1. P. 67-78.

165. Yoshino T., Tabunoki H., Sugiyama S. et al. // Cell. Mol. Neurobiol. - 2011. - 31, N 7. P. 1009-1020.

166. Oo M. L., Thangada S., Wu M. T. et al. // J. Biol. Chem. - 2007. - 282, N 12. - P. 90829089.

167. Liu H. B., Cui N. Q., Wang Q. et al. // Pancreas. - 2008. - 36, N 1. - P. e10-e15.

168. Lien Y. H., Yong K. C., Cho C. et al. // Kidney Int. - 2006. - 69, N 9. - P. 1601-1608.

169. Ushitora Y., Tashiro H., Ogawa T. et al. // Transplantation. - 2009. - 88, N 8. P. 980-986.

170. Hasegawa Y., Suzuki H., Sozen T. et al. // Stroke. - 2010. - 41, N 2. - P. 368-374.

171. Ter Braak M., Claas R. F., Hegen B. et al. // Biochem. Pharmacol. - 2011. - 81, N 5. P. 617-625.

172. Omar H. A., Chou C. C., Berman-Booty L. D. et al. // Hepatology. - 2011. - 53, N 6. P. 1943-1958.

173. Deutschman D. H., Carstens J. S., Klepper R. L. et al. // Am. Heart J. - 2003. - 146, N 1. P. 62-68.

174. Yatomi Y., Ruan F., Ohta J. et al. // Anal. Biochem. - 1995. - 230, N 2. - P. 315-320.

175. Morishige J., Urikura M., Takagi H. et al. // Rapid Commun. Mass Spectrom. - 2010. 24, N 7. - P. 1075-1084.

176. Lee Y. M., Venkataraman K., Hwang S. I. et al. // Prostaglandins Other Lipid Mediat. 2007. - 84, N 3-4. - P. 154-162.

Received 18.06.2012 